\title{
Model of Sustainable Village for Kampung Sedili Kecil in Johor, Malaysia
}

\author{
Maqsood Rezayee, Tan Wee Huat, Norsa'adah Shamsudin, Mathivanan Muthusamy, Sutapa Tasnim
}

\begin{abstract}
The economic growth and energy consumption come at the cost of environmental degradation, sustainability experts are trying to find the way which can reduce pollution, conserve the natural resource and protect the environment. Moreover, regional and rural development strategy pay attention to the goal of sustainability to ensure its continuum. Sustainability such as sustainable ecosystem, sustainable community, sustainable village, and sustainable lifestyle support itself and its surrounding. Moreover, Sustainability ensuring access of human beings to the basic resource, healthcare facilities, education facilities, good quality of life, with capacity of conserving environmental capital, human capital, social capital, economic capital, and cultural capital. Therefore, a sustainable village is designed to achieve the highest levels of ecological and environmental sustainability with a holistic approach to the basic site selection, sub-division planning, and construction, through to the requirements of the built environment. Malaysia is one of the countries which has many villages, the villages are not without problems, which are lagging behind in socio-economic development due generally to prevalence of very low level of literacy, and education and, heavy dependence on primary production, agriculture, animal husbandry, and fishery. Therefore, it is needed to conduct a study to find the strengths, weaknesses, opportunities, and threats of the village. Thus, this research has been conducted to study the Kampung Sedili Kecil village which one of the villages in the Johor state of Malaysia. The main aim of the research is to prepare a model of a sustainable village for Kampung Sedili Kecil to ensure that all capital to be integrated and symbiosis relationship that may enable the continuation of the community and conserved and enhanced the environmental capital, human capital, social capital, economic capital, and cultural capital in the Kampung Sedili Kecil.
\end{abstract}

Keywords: Sustainable, Village, Capital, Kampung Sedili Kecil. Johor, Malaysia.

Revised Manuscript Received on November 15, 2019.

Correspondence Author *

Maqsood Rezayee*, Department of Urban and Regional Planning, Faculty of Built Environment and Surveying, Universiti Teknologi Malaysia, Skudai, 81310 Johor Bahru, Johor, Malaysia. Email:mqsoodrezay@yahoo.com

Tan Wee Huat, Department of Urban and Regional Planning, Faculty of Built Environment and surveying, Universiti Teknologi Malaysia, Skudai, 81310 Johor Bahru, Johor, Malaysia; Email: whtan.engineering@gmail.com

Norsa'adah Shamsudin, Department of Urban and Regional Planning, Faculty of Built Environment and surveying, Universiti Teknologi Malaysia, Skudai, 81310 Johor Bahru, Johor, Malaysia; Email: nor6395@gmail.com

Mathivanan Muthusamy, Department of Urban and Regional Planning, Faculty of Built Environment and surveying, Universiti Teknologi Malaysia, Skudai, 81310 Johor Bahru, Johor, Malaysia; Email: mathivanan_15@yahoo.com

Sutapa Tasnim, Department of Urban and Regional Planning, Faculty of Built Environment and surveying, Universiti Teknologi Malaysia, Skudai, 81310 Johor Bahru, Johor, Malaysia; Email: sutapatasnim@gmail.com

(C) The Authors. Published by Blue Eyes Intelligence Engineering and Sciences Publication (BEIESP). This is an open access article under the CC BY-NC-ND license (http://creativecommons.org/licenses/by-nc-nd/4.0/)

\section{INTRODUCTION}

The economic growth and energy consumption come at the cost of environmental degradation, sustainability experts are trying to find the way which can reduce pollution, conserve the natural resource and protect the environment [1].

Moreover, regional and rural development strategy pay attention to the goal of sustainability to ensure its continuum [2]. Sustainability narrowly defines as the protection or conservation of the physical and biotic environment [1].

In the latter conception, environmental protection is treated as a counterbalance to the main business of developing the economy, creating jobs and providing local people with the services and facilities that they want [1-4].

Sustainability such as sustainable ecosystem, sustainable community, sustainable village, and sustainable lifestyle support itself and its surrounding [1]. Sustainability focuses on environmental protection to avoid destroying the environment and ensure that the impacts of human activity are minimized. Furthermore, sustainability ensuring access of human beings to the basic resource, healthcare facilities, education facilities, good quality of life [3]. Moseley [1] defines sustainability as "the capacity for continuance into long-term future." It is built around the notion of conserving capital, such as environmental capital, human capital, social capital, manufactured capital, cultural capital [1].

A sustainable village is designed to achieve the highest levels of ecological and environmental sustainability with a holistic approach to the basic site selection, sub-division planning, and construction, through to the requirements of the built environment [3]. The sustainable village has water supply, sewerage system and road systems, recycle all water for reuse on-site, generate most of its own energy and make major contributions to its residents' food needs [3].

The model of the sustainable village is important, and it must ensure that the overall vision and objectives will be achieved and must ensure that all homes are energy-efficient, safe and comfortable, that residents' investment and quality of life are protected, as well as physically and socially cohesive community will flourish [3, 4].

Model of development for village is action plan for the development of rural area or areas which are lagging behind in socio-economic development due generally to prevalence of very low level of literacy, education and heavy dependence on primary production, agriculture, animal husbandry, and fishery moreover, social and development of social and physical infrastructures are lagging behind $[3,4]$. Then, for the development of the model, it is essential to give attention to the development of human resources, basic physical infrastructure. A holistic approach in this direction necessitates giving high priority for bringing about improvement in the socio-economic condition of the weaker sections of the population [3-5].

Published By:

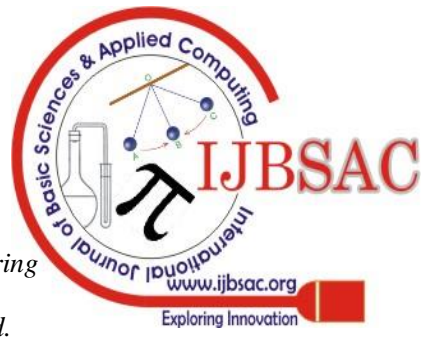
\& Sciences Publication

(C) Copyright: All rights reserved. 
Great rural planners have been given importance to selfreliance and the integration of village resources [4]. It is accepted that the ideal village is not possible to exist, but a complete and continuous effort by including, such as environmental capital, human capital, social capital, manufactured capital and cultural capital in the model will ensure the continuation of the village [4-6].

Malaysia is one of the countries which has many villages, the villages are not without problems, which are lagging behind in socio-economic development due to the prevalence of very low level of literacy, and education and, heavy dependence on primary production, agriculture, animal husbandry, and fishery. Therefore, it is needed to conduct a study to find the strengths, weaknesses, opportunities, and threats of the village. Thus, this research has been conducted to study the Kampung Sedili Kecil village which one of the villages in Malaysia.

The main aim of the research is to prepare a model of a sustainable village for Kampung Sedili Kecil to ensure that all capital to be integrated and symbiosis relationship that may enable the continuation of the community and conserved and enhanced the environmental, human, social, economic and cultural capitals in the Kampung Sedili Kecil.

\section{RESEARCH METHODOLOGY}

The research method for this research is the empirical mix mode research method, which encompasses the qualitative and quantitative data collection based on primary data and secondary data. In primary data collection, sit observations have been conducted on environmental, cultural, and resource aspects.

The interview has been conducted with the chief of the village, local residents and various agencies and institutions (organizations, societies, social facilities, clinics, schools). Moreover, focus group discussions, has been done to find the potentials, issues of the village. Prior to data collection different secondly resources have been reviewed on a better understanding of the current situation of the village. Following the data collection, the gathered data have been taken under the process of examining, summarizing, and analyzing to find the strengths, weaknesses, opportunities, and threats of the village. Accordingly, the action plan has been prepared for sustainable model of Kampung Sedili Kecil. Fig. I shows the flowchart of this research.

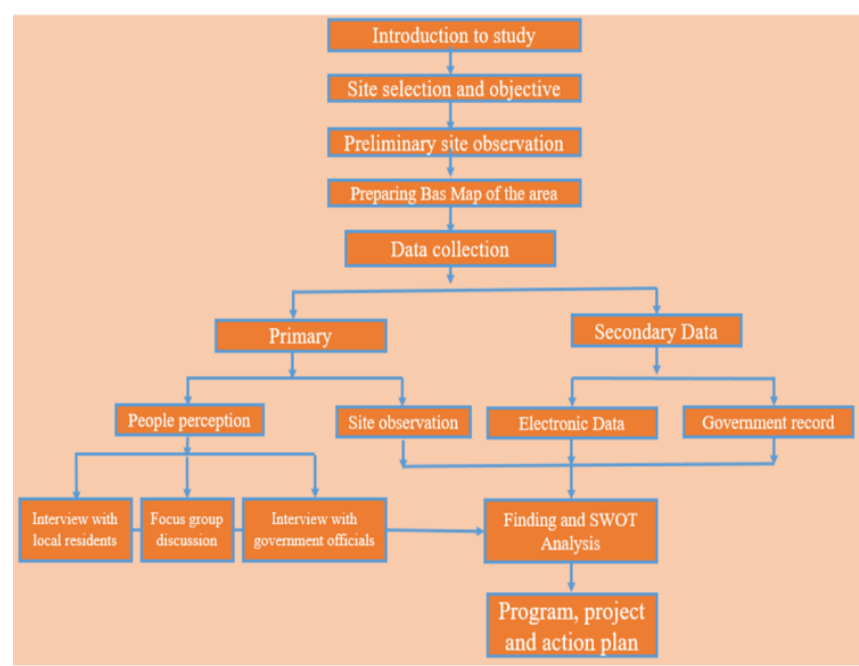

Fig. I. Research flowchart

\section{STUDY AREA.}

Sedili Kecil is a small village located in Mukim Sedili Kecil on the east coast of Johor. The village is located at the mouth of the Sedili Kechil River as it drains into the South China Sea [7]. The Pengerang region which is part of the area under Johor Tenggara Development Authority (KEJORA) shares its border with Iskandar Malaysia but is separated by the Johor River. It comprises of total area 123830 Hectare covers under 5 Mukims [7].

The village is part of Sedili, which includes the town of Tanjung Sedili. Moreover, Sedili Kecil is a traditional Malay fisherman village. The major economies of the local population are diverse [7]. Based on the finding of this research its main source of income comes from fishing, small grocery business and working in nearby oil palm estates.

\section{RESULT AND FINDING}

This section of research presents the finding and results which have been obtained through interview and survey focus group discussion. The result and finding presents the existing situation of each capital: environmental capital, human capital, social capital, economic capital and cultural capital.

\section{A. Environmental Capital}

Environmental capital, which comprises stocks and flows of energy and matter, and the physical states, such as climatic conditions or ecosystems, to which they give rise $[8,9]$. For example, it includes forest, water-quality, river, sea, beach, habitat, soil-condition, climate, topography, land-use, natural beauty, biodiversity, and pollutions [8, 9]. Environmental capital has financial value as the use of this capital can help drives forward both small and large-scale businesses [8, 9].

Based on field survey, there are different grades of rivers and freshwater swamp, besides forests in Sedili Kechil's wetlands making it one of the best examples of wetlands in Malaysia. By the Sedili Kecil River, visitors can see and enjoy the panoramic and ecosystem atmosphere from sandy and rocky beaches and saltwater to brackish and freshwater.

Finding from the focus group discussion states the wetlands in Sedili Kechil have important functions that are often taken easily by most parties. Among its interests include preventing major floods and droughts. The built-in ecosystem in the area serves to store water during the rainy season and release it during the dry season.

The mangrove forest beaches on the banks of the river and coastline are able to protect the nearby area from stormy and stormy violence. Mangrove forests with fibrous root systems can also help prevent erosion of rivers and shores. Mangrove forest in the Sedili Kechil area is located along the Sedili Kechil River, which provides a good habitat for marine life such as fish, shrimp, crab, and shellfish. Microorganisms trapped in mangrove roots become food for fish and shrimp. This, in turn, will attract other animals to live in mangrove ecosystems to form a food chain. Examples of other animals include birds, lizards, turtles, and crabs. Moreover, mangrove is also a valuable resource for the local community. 
Animals such as prawns, crabs, shellfish and fish can be a source of income to local people who are mostly fishermen. While the timber from the mangrove forest is used to build jetty, small bridges, village houses, and firewood. In addition, mangroves can be used as piling.

Furthermore, along the coast, there are several types of plants that grow naturally. Among the major growing and visible plants are Vitex Oxata, Nypa, Carbera Odollam, Hibiscus Tiliaceus, and Terminalia Cattapa.

In addition to the forest, the Sedili Kechil River plays a very vital role to sustain all the ecosystems of the wetland area. The day-to-day subsidence of the rivers and the rainy season in the area is important for the stability of the mangrove forest ecosystem in the area. The river also serves as the main source of fishing for the fishermen and for fish farming, besides, it also serves as a spot fishing sport for the tourists.

Furthermore, based on the village chief, river water and other water sources are not potable. The river water is polluted with oils and sediments. Gombut dam is the only drinkable water source for the villagers. The village itself doesn't have any water reservoir tank. According to some villagers, the pipes itself are quite old and rusty in some places and don't supply very clean water.

According to the village former chief, a small tornado is a common occurrence. It usually between Jun, July, August. He also added that October, November, and December supposed to be heavy rain plus rough wave, however, in the last 20 years' weather became unpredictable.

The village chief states, tidal flooding is something that happens once in a while, besides, monsoon flooding happens sometimes as well. The authority has already upgraded the drainage system to combat these issues. In 2017 there was a powerful hurricane that destroyed 10 houses and a school. After that, the villagers formed a natural disaster group to create awareness and spread news of upcoming natural disasters to lessen the number of damages. They get information about upcoming disasters from the local authority.

Based on the focus group discussion, the Sedili Kechil village lacks a proper drainage system. All the drains are left open making it breeding ground for insects and mosquitos. The drains also dump into either river or sea, which intern further pollutes the water. Besides, according to the current village chief, overall pollution problem is not that serious. But there are some wetlands reports mentioning water pollution from oil spills from the jetty and subsequently, nearby air of the jetty area gets polluted from all the black smoke released from boats.

According to villagers often times fishermen would illegally discard remaining oil into the river or open sea areas after cleaning the engine of their boat. They mainly do this to avoid paying fees at the jetty for using proper services. There have been some recorded cases of this instance. This oil discarding effects the water from Sedili up to Mersing, making the water not usable for daily use and killing and eventually migrating value-earning fish and crab population from the affected area.

\section{B. Human Capital}

Human capital, which comprises the ability of individual people to do productive work, whether paid or unpaid and therefore includes their physical and mental health, their

strength and stamina, their knowledge, skills, motivation, and attitudes [2]. Improvement of human capital provides people with the capacity, knowledge, skills, attitudes, and motivation to reduce the harmful influence of society on the environment and to protect and preserve the globe for future generations [2]. Therefore, human capital is defined in the skills which encompass the productivity, capacity, and capital of individuals contribute to his or her own well-being and well-being of the community $[2,11]$.

Human capital is a central factor in the process of model of sustainable because the effects of investment in human capital are usually the same and in some cases even bigger than investments in other forms of capital [2,12]. The benefit from investments in human capital multiplies much more quickly than the benefits of investments in other forms of capital [2]. Therefore, emphasizing the human capital would result in a faster rate of development, and sustainable development of society as well as would equitable distribution of development benefits [2].

Human capital includes the skills and qualifications, education level, work experiences, social skills, intelligence, judgment, personality, hardworking, habitats and personality trait, creativity (ability to innovate new working practices), as well as the ability of people to do productive work, their physical and mental health, their strength and stamina, their knowledge, skills, motivation, and attitudes [2, 12].

Based on the village current chief the total population of the Kampung Sedili Kecil is 1403 and the numbers of households are 255 houses. Malay is the more dominant population with $100 \%$, Chines and Indian are $0 \%$ in the village. Less than $10 \%$ of population who are mostly the old and senior people suffer physical disability. The family is not too large and is a single-parent family, thus, every household includes 5-7 persons. Furthermore, $2 \%$ of the population live in poverty. Besides, $50 \%$ of the young generation is willing to stay in the village and $50 \%$ of them are willing to migrate to urban areas. The education background of the villagers can be categorized into categories, for instance, primary education, secondary education, tertiary education, religious education and skills from family background. Table-I shows the demographic characteristic of Kampung Sedili Kecil.

Table-I: Demographic characteristics of Kampung Sedili Kecil. Source: Field Survey

\begin{tabular}{|c|c|c|}
\hline Total popu & & 1403 \\
\hline Number of & & 255 \\
\hline Age & Male & Female \\
\hline$>60$ year & 48 persons & 59 persons \\
\hline 40-59 year & 155 persons & 208 persons \\
\hline 18-39 year & 139 persons & 195 persons \\
\hline 13-17 year & 89 persons & 114 persons \\
\hline 7-12 year & 74 persons & 89 persons \\
\hline 5-6 years & 49 persons & 58 persons \\
\hline $0-4$ years & 57 persons & 69 persons \\
\hline Total & 611 & 792 \\
\hline
\end{tabular}

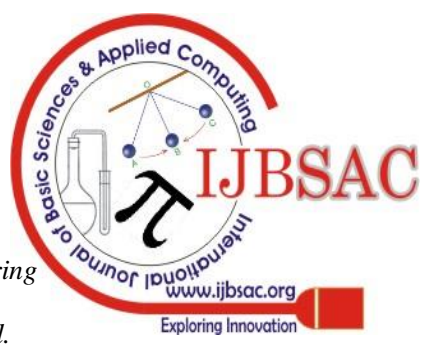


Based on focus group discussion working on agriculture land, fishery, small construction, breeder, farmer, small business, barber is tailor the major jobs in the Kampung Sedili Kecil, however, many residents are unemployed. According to interview with local workers, most of the employees in the area are nonskilled. For example, most fishermen prefer to do fishery in traditional way and are mostly nonskilled. Besides most of the workers prefer to have more free time in the evening, therefore, they are going for the fishery at $5 \mathrm{am}$ and will come back at $10 \mathrm{am}$. In addition, most fishermen do not have fishery licenses to follow the rule and regulations of the fishery. And the farmers mostly work on personal land to have flexible time.

\section{Social Capital}

Social capital, which relates not to individual people but to the social structures, institutions and shared values that enable individuals to maintain and develop their human capital and to be productive. It, therefore, embraces firms, trade unions, families, communities, informal friendship networks, voluntary organizations, legal and political systems, educational institutions, the health service, financial institutions, and systems of property rights [12]. Social capital also can be used to support, development of a community This is similar to other forms of capital, which can be used to benefit society [12].

Based on the site visit, educational institutions are available in this village as follows, kindergarten, primary school, religious school. Secondary school is only available at Tanjung Sedili which is located about $13 \mathrm{~km}$ from Kampung Sedili Kecil. The highest level of education in this village is bachelor level at local universities. Furthermore, a lot of skills training have been arranged in this village especially by Fishery Development Authority of Malaysia (LKIM) to give training to the fishermen to develop their skills in fishing and how to increase their monthly income.

Based on the observation, there is only one rural clinic in this village. Villagers can obtain basic medical treatment at this rural clinic whereas major treatment is only available at the health clinic in Tanjung Sedili and medical premises at Bandar Penawar and also government hospital at Kota Tinggi. In addition to a clinic and schools, there are few other social services available at Kampung Sedili Kecil. From visual observation around the village, researchers notice few public amenities such as community hall, mosque, commercial area, free WIFI service, football field, and signal tower. All these public amenities were made for public usage and make villagers' life easier.

However, there is no financial institution such as Bank or ATM service available at this village. Villagers need to access to Kota Tinggi or Bandar Penawar for this financial service. Moreover, the social group or society in Kampung Sedili Kecil is found being at active status. For example, Women Society (KUNITA) is one of the most active societies in Kampung Sedili Kecil where they regularly arranging events to celebrate important days such as Father's Day, Mother's Day. In addition, Youth Society also involved in arranging sports-related activities such as football competitions.

\section{Economic Capital}

Economic capital, which comprises material goods such as tools, machines, buildings and infrastructure, and fishery, all of which contribute to the production process without becoming embodied in its output [14]. Economic capital has vital role in the broadening of land-based activities such as protection and management of land resources, the production of new crops which benefit local people as well as attract visitors and investors [13]. The use of existing and new human capital for off-farm activities such as offering transport for people and goods to the nearby commercial center, as well as activities such as homestay to diversify rural household income sources also needs the support of economic capital [14].

Based on interview with the chief of village under the jurisdiction of Pihak Berkuasa Tempatan Pengerang (PBPT) which emphasis on Economic Transformation Programme (ETP) launched by the government in 2010, Sedili Kecil has tended to provide more ground for free-market approach with the development of rural infrastructure and incentives for private capitals in rural areas. Mainly there are three types of economy modes such as plantation, cultivation fishery and small enterprise which generate income for Sedili Kecil residents.

\section{E. Cultural Capital}

Cultural capital which related to the intellectual, spiritual, aesthetic development of an individual or group a range of intellectual and artistic product including film, art theatre, activities, beliefs (religion), customs and tourism $[12,15]$.

Based on-site visit valuable historic buildings found in the area is the old village mosque named Masjid Jamek Kampung Sedili Kechil. It has high historical and architectural value. Sedili Kecil evolved from a small settlement into a traditional Malay fishery and farm village. Fishery skills and farming was inherited and continued by generation. Therefore, it becomes favorable compared to other jobs and contributed the most to the local economy for decades. They are preferred because of their flexible working hours and qualification required, and at times brings high return. Skills, equipment, and ownership are fully owned by the locals with some support from the government to encourage growth. Farming activities were original of local fruit orchard before it was turned into a more profitable oil palm plantation. However, there is still some local fruit and vegetable farm that remains for local market. Other products from fishery activities that are turned into small businesses are shrimp farming, horseshoe crab breeding farm, freshwater fish breeding farm, production of salted fish, sports fishing, collecting river clams and arts and crafts from sea.

Entering the serene village can become a memorable experience. With its small population and remoteness, one can enjoy a quiet and peaceful atmosphere of the village. Very fewer vehicles pass by on day time and become even lesser as night approaches. Another main attraction to this small village is its long stretched beach facing the south china sea namely Tanjung Buluh Beach and Sedili Kecil Beach. Tanjung Buluh beach has the most beautiful view, white sand, and clear water.

The livelihood of the local community of Sedili is connected to the wetlands.

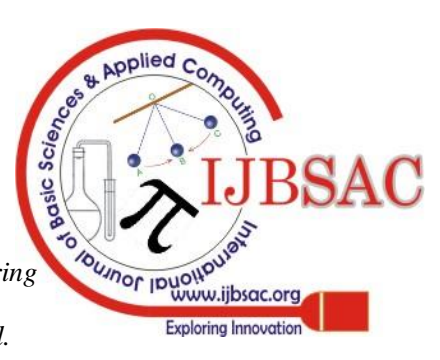


Fishing is an active part of their daily lives. Leaves and plant extract from the trees are used as local resources in infrastructural, medicinal and cultural aspects of their lives. The leaves of this palm are prized for traditional roofing thatch and the trunks are useful for Kelong (fish traps) and can be split and used as floorboards.

Seashell and ocean products can be produced for fashion accessories, bags, bracelets, hairclips, earrings, slipper, placemat, curtain, boxes, lampshades, photo frames, table decors, and many other handicraft items. The raw material can easily be found from the nearby beachfront or for the larger-scale industry may be cultivated as not to threaten the existing natural eco-system.

\section{SWOT ANALYSIS}

SWOT analysis is applied to study the strengths and opportunities of the site and to find out the weaknesses and threats that may hinder the development effort.

\section{A. Strength}

In term of environmental capital, Sedili Kecil has different types of natural sites with serene beauties within a very short distance which makes it a very attractive place to Sedili Kecil catchment, being entirely forested provides an excellent opportunity to conserve a relatively intact ecological system Furthermore, Sedili Kecil has a relatively intact natural habitat, rare animals, birds, fish, plants.

In term of human capital, there are education facilities and opportunities of secondary school for the young generation. Furthermore, the equality of women in terms of doing a job and working gives them the opportunity to have their own income as well as male and female work to support the family. The population is growing which increases human capital in the future. Moreover, increasing the number of active women decrease in the number of unemployed women and consequently the number of unemployed people.

In term of social and economy capital, the government has provided Kampung Sedili Kecil with the basic facilities for the villagers to live in harmony state. Moreover, Kampung Sedili Kecil villagers have an open-minded and they can give full support (no objection) for any upcoming developments. Furthermore, since Kampung Sedili Kecil has many attractive beaches, this may lead to further development to tourist attraction which indirectly can cause progress in social facilities at this village and enhance social capital of the Kampung Sedili Kecil villagers.

For the cultural capital the local community of the existing traditional village is committed and keen in keeping the serenity and peacefulness of the area, yet very friendly and helpful. Moreover, this area had gathered interest by many researchers, agencies and individuals for its beauty, richness in natural resources, potentials in the economy and recreational purposes.

\section{B. Weakness}

Form the view of environmental capital although Sedili Kecil is very rich in term of natural beauties they are hardly maintained properly. The main reason being lack of initiatives from governmental bodies and poor implementation of laws. Moreover, river and sea-front are polluted with waste dumps from the drainage system and oil dumping from boats which are harming the mangrove and visit and get different types of experiences. Besides, the

vegetation. Furthermore, Sedili Kecil has started to face more natural disasters like cyclones, flooding, tornado in recent years which is also affecting the life of people and the ecology of this area.

In term of human capital number of people are unemployed, in addition, there are many people with a physical disability. Beside, in term of skill, most residents are nonskilled they are working traditionally and are not commitment to regular jobs. Furthermore, the residents do not possess the capital and skills to adapt to different jobs, and there is an unmet demand for specialized workers. Moreover, half of the young generation are willing to move to urban areas for better economic opportunities, it will cause the prevalence of the elderly population and the tendency towards further aging of the population. The shortage of persons with high education levels in the area is another weakness, and in terms of language, the residents cannot speak international language to attract foreign tourists.

From the view of social capital, drug abuse is one of the most critical issues found in Kampung Sedili Kecil which is involving teenagers and youngsters. Although there are many job opportunities in or nearby the village the villagers have attitude issues as they are not interested to work in those fields. The small rural clinic found in this village has not undergone any upgrading process and some of its buildings look old which constructed from wood. The telecommunication signal and internet connection are very poor in this area. The main road there not supplied with enough street lights which might cause accidents and affect the safety of the road user.

In terms of economic capital, the villagers behave less committed toward changing the current lifestyle from daily inconsistent income as compared to monthly salary income basis. The overall education level is considered low whereby the qualification to adopted technology and knowledge in the higher end seems to be difficult and challenging. The telecommunication signal and internet connection (ICT) not up to expectation which is much required to attract investment.

From the aspect of cultural capital, it has a low population either contributed by low numbers of childbirth or migration of the locals to the cities. This somehow becomes a big setback to the development as it lacks local human resources. Furthermore, the local people are still lacking awareness on some important aspects of living such as; cleanliness, health, wellbeing, and happiness. This is perhaps due to the standard of education and mindset.

\section{Opportunity}

For the environmental capital, Sedili Kechil has the potential to become a popular eco-tourism site because of its various natural beauties. Moreover, by conserving the current wetland area, it can become a research site to study the rare species found in this area and understand their value in the ecological system on a wetland site. Cleaning the river and preventing further pollution on the river can help restore the fish and crab population and have a positive effect on the ecology.

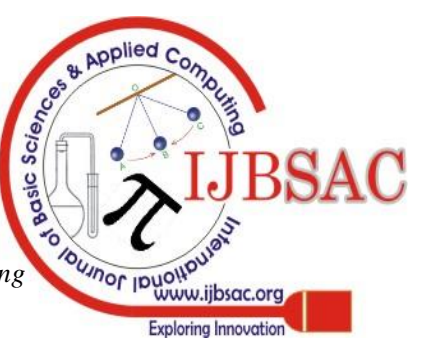


In term of human capital, there are self-employment opportunities. More intensive cooperation among the community and educational institutions as regards the vocational training and specialization. As well as the population density is low in the village it gives opportunities to increase population and workforce expansion through immigration.

From the view of social and economic capital, the Kampung Sedili has the capacity to upgrade the lifestyle of villagers. The social facilities can be upgraded more for further convenient lifestyle as there are still a lot of lands to develop. Furthermore, the existing economy activities which generate income to villager have high potential to upgrade for value-added. Besides, there is existing land which is vacant or not fully utilized could be transformed into other activities to generate more income. As well as the track record of existing investment merge well with the villagers could be a good referral factor for other investors.

In term of cultural capital by conserving and preserving the originality, historical values and traditional way of living including other traditional elements found in Sedili Kecil, can contribute to rural tourism as an attraction and become a pull factor for tourism industry. Tourism as the new economy of the area may lead to new potential of large industry from the sea such as seashells and ocean crafts, and hospitality such as resorts and beach chalets.

\section{Threats}

In the environmental capital aspect, the Sedili Kecil River is suffering from pollution from the oil palm plantations that release their waste without proper control. In addition, locals have low knowledge about their environment which leads to them polluting it in various ways like dumping boats oil, open drain and waste dumping at the river. The current jetty is also not maintained properly so that also leads to oil spill into the open sea. Besides, the river is also responsible for erosion which leads to mangrove forests being swept away leaving devastating effects.

In term of human capital, drug abuse is the most critical issue in the Kampung Sedili Kecil. Many residents addicted to drug, which will cause the addiction of more people. Moreover, the outflow of young generation, which will cause unfavorable age structure of employment, and aging workforce, as well as the shortage of specialized workers.

In term of social capital new programs and event might not get full support from villagers, Attitude of the villagers remain unchanged even though many improvement programs have been conducted by relevant parties.

Less interest or respond from villagers upon promoting new economic activity as entrepreneurs or partnerships by public or private treats the economic capital. Drug abuse may lead to a higher crime rate which causes the investor to be less willing to take risk.

Finally, in term of cultural capital traditional villages and its Malay heritage culture may face the risk of disappearing following rampant development of its surrounding neighbor or uncontrolled development.

\section{PROGRAM AND PROJECT}

This part of research aims to prepare a model of a sustainable village for Kampung Sedili Kecil to ensure that all capital to be integrated and symbiosis relationship that may enable the continuation of the community and conserved and enhanced the environmental, human, social, economic and cultural capitals in the Kampung Sedili Kecil.

\section{A. Program and project for Environment Capital}

The wetland of Sedili Kechil needs to be conserved and preserved at its current state. The local authority needs to take action to make sure the area is protected. This should also be reflected in the policies to ensure the conservation of the Sedili Kechil wetland area. A strict policy and implication should be in place to stop water pollution. Factories should be subjected to abide by these rules and filter out their waste before safe disposal. Fishermen should be subjected to safe disposal of oil after boat cleaning as well. The local authorities should be responsible to monitor these.

In addition, the area needs proper Municipal waste management regular garbage collection should be implemented in order to stop the open burning. The villages need to have properly designed covered drainage systems, the local authority also needs to plan and construct a proper drainage system to remove the current open drainage. Besides, the current drainage system needs to stop dumping wastewater directly to the sea.

Educating the villagers is a dire need action in the village to aware the villagers how their action is leading to the pollution of their environment. Therefore, it is necessary to arrange seminar and workshops to encourage them to take better care of their environment.

The fishermen community should be educated about the after-effects of the oil spills at the river. They should be encouraged to use proper boat cleaning facilities at the jetty rather than dropping excess oil at river. The local authority needs to monitor nearby industries needs to make sure they do not dump waste into the river or sea-water.

The low scale use of its wetland forest products by local communities can only be continued if these resources are protected from non-sustainable exploitation or destruction. These low scale uses, provide significant benefits to the local communities. It is important that conservation measures to be taken before these valuable genetic resources are lost.

\section{B. Program and project for human capital}

In term of drug abuse, the seminars should be arranged by the government to increase the awareness of the residents toward the harm of drug. Proper skill development programs should be provided, to enhance the skill of the residents to have a better catchment and increase their benefit. Besides, the fishermen are lack of modern fishing techniques so they need training. Then, the fisheries department should arrange proper training for the fishermen. As result, they can have better catchment through the usage of all those fishing techniques.

There should be language training courses for English and other foreign languages, to make it easier for the locals to communicate with the foreign and have better catchment in term of tourism. Farmers need to be encouraged to plant different fruits, vegetables and raise animals.

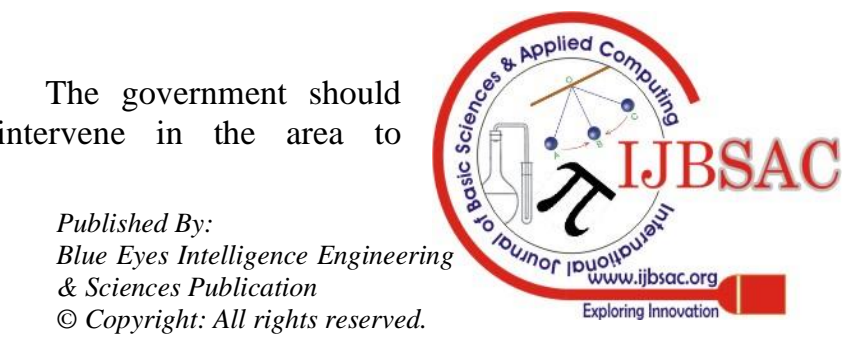


improve the employment rate in the community especially for youth as most youths are shifting outside for better opportunities. In that regard, the special quota should be introduced to ensure the employability of local people.

\section{Program and project for Social Capital}

Besides fishing, other sea-related industries such as mussel's cultivation, arts, and craft, shell collection, horseshoe crab cultivation should be high priority as a profitable source of income. Research and development programs should be carried out on testing the soil suitability for better crop plantation where the farmers can explore the new plantation with the available farming knowledge with some assistance, training, and marketing from the relevant agencies.

The government has to introduce the micro-credit finance program for the locals to start small businesses, to have more earning opportunities. The local people can avail of micro-credit finance to invest in the area by running small businesses. Furthermore, there is a good demand for ICT shops which small business can provide. The villagers also need skill training for ICT operation and services.

\section{Program and project for Economic Capital}

Based on site observation, there is plenty of lands are not fully utilized especially those houses with empty land surrounding. The dimension of broadening involves explore the potential existing land use, innovate new activities which can generate additional income for every household.

Kampung Sedili Kecil seems like suitable to encourage additional income-generating activities but minor upfront money investment such as honey harvesting for the production of honey, leech cultivating for production of traditional medicament, red worm composting for production of organic fertilizer.

The plantation activity within this vicinity is mainly palm oil plantation. However, the recent lower price of palm oil has hit hard on the villagers which rely on palm oil plantation. There is a need to diversify the plantation to produce variety of products. As observed, the climate at Sedili Kecil is suitable for plantation of "Durian Belanda". This premium fruit had become popular and rise in demand as could be a good option of income diversification for villagers as compare rely fully on palm oil which has been volatile for a long time.

There is an existing homestay site which being abandoned or discontinued due to mismanagement. The proposal could be made through relevant agencies to refurbish these homestays to continue its function as homestay to attract and boost the tourism for Sedili Kecil. Besides refurbishing, the homestay site could be sustainable in the long run and make ease from natural treat (land erosion due to strong tidal wave). There is a need to protect the shoreline with engineered revetment wall. The protection and management of land resources shall provide more area and opportunity to the locals.

Based on site visit there is a sign of grouper harvesting farm at the river mouth but as well discontinued. An interview states the inconsistent water quality in the year 2015 has resulted in a huge loss and cause the cultivation to discontinue. However, it has been all equipment and tools for grouper cultivation are still in good condition. The suggestion will be to look for other alternative species other

than grouper. The calm tide at the river mouth is suitable for mussel harvesting which is agreed by interviewees.

The existing Kampung Sedili Kecil's economy activities show signs of various potential and worth to expand or deepen to explore more by introducing new methods or technology to the existing economic activities. The usage of chemical fertilizer or pesticides has cause treat to the environment and health issue for continuity period of time. The introduction to using organic farming shall be good start and option of pain reliever for the villages. Organic farming has been a proven method which is sustainable and produces higher productivity and cost-efficient in the long term. The implementation of organic farming could as well boost the demand for compost and stimulate more villagers in red worm harvesting.

\section{E. Program and project for Cultural Capital}

With the abundance of sea-life, the shell-art and craft industry may bring good returns to the Sedili Kecil economy, without threatening the existing eco-system. Traditional games, recreational past time, traditional village concept homestays, daily services, laundry service, mini market may attract tourists to make a longer stay in the village and generate new economy to the local.

In order to make all plans into action, the first and foremost the government must start with upgrading the major infrastructure works such as building a wider and better road that is connecting to this village from the major roads complete with proper streetlights, upgrading the existing telecommunication towers to provide better connectivity and internet lines.

\section{CONCLUSION}

The Sedili Kecil watershed in Kota Tinggi District of the state of Johor in one of the very few catchments in Peninsular Malaysia that remains entirely forested from its source to estuary though most of the forest had been logged over. The Sedili Kecil ecosystem holds high biodiversity value and is of socio-economic significance. The region contains a large area of the highly threatened freshwater swamp forest ecosystem including excellent examples of mangrove, brackish water, and riverine vegetation. These ecosystems support a large extent fish stocks of the mangrove and river which in turn support the livelihood of local communities. The mangrove forests also play an important role in reducing the effects of erosion.

The pristine mangrove forest along the lower reaches is considerable value as a potential conservation area. The plants found in or near the wetlands are directly beneficial to the wealth and health of the people.

Considering all the capitals discussed above, and the SWOT analysis for each capital, it is important that this area be conserved and its potentials be explored. The tourism industry of this area that includes the eco-tourism, agrotourism and rural tourism potentials must be made clear to the locals to catch on. Many would not even consider nature conservation as a respectable means to earn a living. It is hoped that by building capacity within the community, starting with young nature guides, the locals can begin to value nature for its own sake.

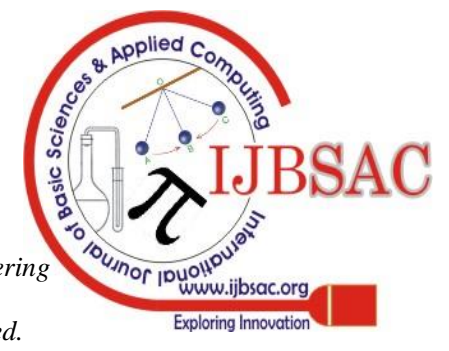


Sedili Kecil's storyline must be carefully crafted, orchestrated and presented the journey through specialized ecosystems with diversions into sustainable uses, community interaction, ecology, and conservation. By having all the props in place, the gradated eco-system with their specialized plants and wildlife, it just needs insight and enthusiasm to write the plot and direct the cast.

\section{REFERENCES}

1. M. j. Moseley, Rural development principle and practice. SAGE Publication, London, 2003, pp. 2-57.

2. V. Barefield. (2009). Discussion of human capital and rural economic development. Journal of Agricultural and Applied Economics. 41 (2), 431-433.

3. K. Majumdar. (2015). Sustainable Village Development Plan with People's Participation: A Case Study of a Multi-ethnic Village of Jharkhand. The International Journal of Humanities and Social Studies. 3(7), 2321-9203.

4. M. Fahmy, M.M. Mahdy, and M.F. Abdelalim. (2017). A Proposed Methodology for Planning a Sustainable Village at Mid Sinai Arid Climatic Zone, Egypt. International Journal of Environmental Science and Development. 8(12).

5. K. Pezzoli. (1997). Sustainable development: A transdisciplinary overview of the literature. Journal of Environmental Planning and Management.40(5), 549-574.

6. R. Jabareen (2006). Sustainable urban forms: Their typologies, models, and concepts. Journal of Planning Education and Research. 26 (1), 38-52.

7. I. Nather Khan, M.A. Firuza, and A.S. Aziz. (2013). Ecology and conservation values of Sedili Kechil Wetland. Ecology, Environment and Conservation. 19 (3), 543-651.

8. C. Cho, M. Freedman, and D. Patten. (2012). Corporate disclosure of environmental capital expenditures. Accounting, Auditing and Accountability Journal. 25 (3), 486-507.

9. D. N. Pena, V.R. L. Ruiz, and Jose. L.A.Navarro. (2015). The Effects of Environmental and Social Dimensions of Sustainability in Response to the Economic Crisis of European Cities. Sustainability. 7, 8255-8269.

10. J. S. Coleman. (1988). Social Capital in the Creation of Human Capital. American Journal of Sociology. 94. 95-120.

11. J. M. Pennings, K. Lee, and A. V. Witteloostuijn. (2017). Human Capital, Social Capital, and Firm Dissolution. Academy of Management Journal.41(4).

12. A. Kay. (2006). Social Capital, the social economy and community development. Community Development Journal. 41(2), 160-173.

13. D. DeSteno. (2009). Social Emotions and Intertemporal Choice: "Hot" Mechanisms for Building Social and Economic Capital. Current Directions in Psychological Science.18(5), 280-284.

14. V. Jarness. (2017). Cultural vs Economic Capital: Symbolic Boundaries within the Middle Class. Sociology. 51(2), 357-373.

15. J. H. Goldthorpe. (2007). Cultural Capital: Some Critical Observations, in Sociologica. Italian journal of sociology on line. 2/2007.doi: 10.2383/24755.

\section{AUTHORS PROFILE}

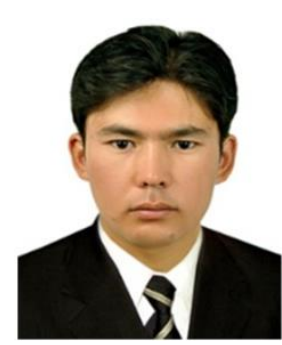

Maqsood Rezayee, graduated from Kabul Polytechnic University in 2014 with Bachelor of Science in Architecture Department Faculty of Construction. Following that he entered to an academic assessment and examination to be selected as an academic member of Nangarhar University and passed the assessment with the highest score. Then, in 2015 he accepted as fulltime lecturer at the Department of Architecture, Faculty of Engineering at Nangarhar University, Afghanistan. After 2 years of teaching at the Architecture Department in 2017, he got an offer letter from Universiti Teknologi Malaysia to study Master of Science (Urban and Regional Planning) in Faculty of Built Environment and Surveying, from which he graduated in 2019. After graduation from Universiti Teknologi Malaysia, he is continuing full-time lecturer position at the Department of Architecture, Faculty of Engineering at Nangarhar University, Afghanistan.

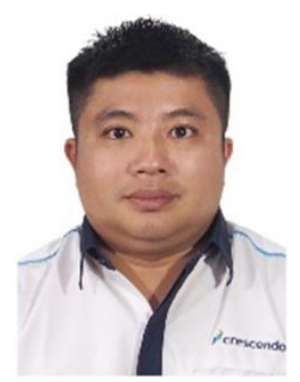

Tan Wee Huat, graduated from Universiti Teknologi Malaysia in 2005 with Bachelor Degree (Hons) of Civil Engineering. Started his career as practicing civil engineer engaged by civil and structural consultancy firm from 2005 to 2010. Under the supervision and guidance of professional engineer, he has gained much experience in reinforced concrete structural as well as infrastructural design. He has also established two years' working experience as resident engineer by supervising marine construction works. He is a project manager for a reputable public-listed property developer since 2012. He has been appointed as the company's management representative since 2017 and managed to obtain and maintain ISO 90012015 certificate for 2017, 2018 and 2019. At the moment, he is pursuing Master of Science (Urban and Regional Planning) at Universiti of Teknologi Malaysia.

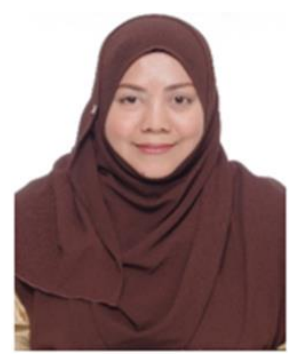

Norsa'adah Haji Shamsudin, was an Architect at various Architect firms since 2002 before joining the public service in 2006. At present, she holds the position of Senior Architect at The Public Works Department of Malaysia and pursuing her Master's Degree in Urban and Regional Planning at Universit Teknologi Malaysia and in her final semester. For the past 20 years in the construction industry, she was involved with hundreds of projects from housing, commercials, and public buildings. Although her expertise is Architecture, her interest and experience in Town Planning brought her involvement into various planning committee at municipal, state and national level, representing her department. She had vast experience in preparation of Development Proposal Reports, Planning for Village Growth Centre, Local Plans and State Structure Plans.

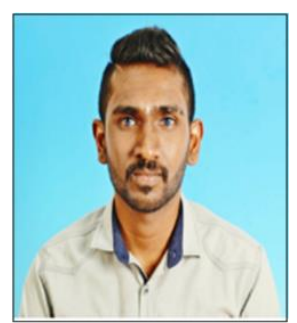

Mathivanan A/L Muthusamy, is graduated from National University of Malaysia in 2012 with Bachelor Degree (Hons) of Civil and Structural Engineering. He has started his career in engineering field where he has worked with MMC Gamuda KVMRT(T) Sdn Bhd as a Site Engineer under Geotechnical department for one of the mega project in Malaysia which is MRT 2 underground package. Throughout his working experience, he has learnt many experience in geotechnical aspects, structural, and as well as project management and public relation. Currently, he is pursuing higher education in Master of Science under Urban and Regional Planning at Universiti Teknologi Malaysia.

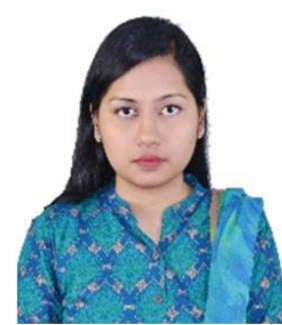

Sutapa Tasnim, is a Registered Architect with working experience of 3 years. She is currently working as an Urban Planner at Surbana Jurong Private Limited, Bangladesh Branch since August 2019. Her first degree was Bachelor in Architecture from Ahsanullah University of Science and Technology, Bangladesh; she graduated from it in 2016. After that, she pursued her postgraduate degree Masters in Urban and Regional Planning from Universiti Teknologi Malaysia, Johor, Malaysia; from which she graduated in 2019.

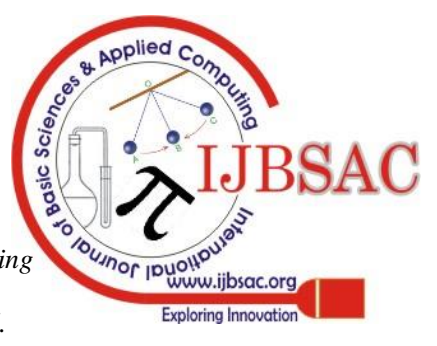

